\title{
Scientific provenance of accounting
}

\author{
Mieczysław Dobija*, Bartosz Kurek \\ Cracow University of Economics, Cracow, Poland \\ *Corresponding author e-mail: accountd@uek.krakow.pl
}

\begin{abstract}
The commencement of accounting is dated at the outset of civilizations. Instead, the science age began less than five centuries ago. Numerous discussions concerning the recognition of accounting as one of the academic disciplines emerged in the American literature recently. Therefore, the question whether accounting truly belongs to academic disciplines or not is the current issue. However, the former consideration should be formulated differently, since that matter is much deeper than the original problem. Therefore we state the following question: "Is accounting a sort of science or not?". The study presented in this paper demonstrates that accounting fulfills most of conditions that are essential to consider its scientific provenance. Theory of capital, which is briefly discussed in the article, is a significant part of accounting, which proves that our discipline is the real science. Accepting the statement that the measurement process requires the recognition of what is measured in the first place, it is clear that the recognition of capital belongs to accounting as well. All these deliberations lead to the conclusion that scientific fundamentals of accounting theory enable accounting systems to provide good services for the entire economy.
\end{abstract}

Keywords: Capital Theory, Science, Scientific Accounting

\section{Introduction. In search for the kernel of science and accounting}

According to one of the regulations [42] issued by the Ministry of Science and Higher Education of Republic of Poland, accounting is not a separate academic discipline in Poland. However, that regulation is "just" a legal act, which "just" regulates the notation of academic disciplines. We are deeply convinced that the issuance of any law cannot change the true nature of the matter under consideration. Therefore more scrutiny is required to deal with the problem of excluding accounting from academic disciplines.

From time to time some papers - that relate to the recognition of accounting as a part of academia - are published in American accounting journals, as well as in Polish literature. These papers are usually controversial. In 1924 H. R. Hatfield [25] managed to defense accounting. In 1963 in Poland T. Peche [35, p. 10] claimed that accounting theory is not an academic discipline (pl. dyscyplina naukowa), although in 1988 he claimed that accounting is an academic discipline, and that discipline in English language is called "accountancy" [41, p. 59]. Currently M. Kwiecień agrees with T. Peche's former belief. Recently two authors: J. S. Demski [9] and J. C. Fellingham [22] - who undeniably belong to the group of leading American researchers - wrote their articles under the same title: "Is Accounting an Academic Discipline?". J. S. Demski concluded that currently accounting is not an academic discipline, although it could and should be one. On the other hand J. C. Fellingham gives the affirmative answer to the stated question, although some changes in the behaviour of academics should be made.

The discussion with these two papers (by J. S. Demski and by J. C. Fellingham) has recently been undertaken by M. Dobija [12] and by A. Szychta [44]. M. Dobija claims that the following question should be stated instead: "Is accounting a scientific discipline?". M. Dobija shows evidence that accounting is in fact a scientific discipline. Moreover, this author explained that the consistency of a particular knowledge with the fundamental laws of Nature is the major determinant of a significance of that knowledge for the development of civilizations.

At this moment the notation used in this paper should be clarified. It is well known that the word "science" comes from the Latin "scientia", which means knowledge. According to the Webster's Dictionary [24, p. 2032] science can be defined in many ways, some of these being:

- "possession of knowledge as distinguished from ignorance or misunderstanding",

- "accumulated and accepted knowledge that has been systematized and formulated with reference to the discovery of general truths or the operation of general laws",

- "knowledge obtained and tested through use of the scientific method", 
- "a branch of study that is concerned with observation and classification of facts and esp[ecially] with the establishment or strictly with the quantitative formulation of verifiable general laws chiefly by induction and hypothesis".

Summing up, science refers to a system of acquiring knowledge, and therefore the purpose of science is to produce useful models of reality.

In an academic language the term "science" is used in conjunction with such adjectives as: "natural" or "social". The term "social science" is used to describe such disciplines as: economics, law, sociology, psychology. The term "natural science" is used to describe such disciplines as: physics, biology, chemistry. On the other hand the term "humanities" denotes such disciplines as: literature, music, religion, history and philosophy. In this paper we try to prove that accounting truly belongs to natural sciences, although the adjective "natural" will be skipped most of the time.

To compare and contrast accounting with science we need after all to point out the existence of general laws that have been discovered, examined and explained in accounting theories.

J. Apanowicz [1, p. 14] distinguishes three classes of sciences: practical, formal and empirical. Other authors distinguish only formal and empirical sciences. It can be proved that accounting posses all three features, although in varying degrees.

Let us start from the first class. Our discipline is undeniably very significant in economic life, as it feeds socioeconomic life with vital financial information. Accounting is therefore a practical science. That feature can be read from accounting definitions, giving just an example of a definition by Y. Ijiri [26, p. ix]: "accounting is a system designed to facilitate the smooth functioning of accountability relationships among interested parties". Furthermore, accounting is frequently refereed as a "language of business" or an "international language of business" [26, p. 14], [30, p. 1], [39, p. 5], [43, p. 13].

Various accounting systems are commonly and broadly used in practice. It is a main tool in maintaining homeostasis in economic units. Retrospective financial statements cooperate with prospective "pro forma" statements linking performance with budgeting and vice versa. Managerial accounting provides useful models for solving short-term and long-term problems and making rational decisions. Moreover, an influence of accounting information on management decisions or market behaviors is constantly in agenda of research studies. Furthermore theories of auditing accounting information are constantly studied as well. Therefore it is clear that accounting is absolutely a practical science that serves managers in their everyday work. It is so practical that it sometimes throws shadow on the scientific side of accounting theory.

Formal sciences - the second class of sciences - study the pure structures, exactly as mathematics and logic. Thanks to M. Mazur [38, p. 14] we know that cybernetics also belongs to formal sciences. These consistent theories of abstract structures are formal in the sense that they concern a form rather than a content. They are non-empirical. The structures are constructed, theories are precise and well defined but they do not map the reality.

Accounting at least has aspirations to be recognized as a formal science. Some authors, such as D. Ellerman [20], [21], used formal mathematical language with the aim to formalize a double entry recording. These publications may be discerned as a sort of curiosity or peculiarity. However, the most profound papers in this field were written by Y. Ijiri [27, 69-85], [26, pp. 51-69] and R. Mattessich [37, pp. 83-86], who managed to form axioms in our discipline. Y. Ijiri described three axioms and R. Mattessich described 21 axioms.

Empirical sciences - the third class of sciences - arise as a result of an ongoing cycle: observations -> theory -> observations $->$ theory, and so on. These theories are non-formal although mathematics, logic, and cybernetics may be employed by them to analyze the results and the models obtained and discovered from an empirical material. The general method of empirical research is to connect facts and form hypotheses. Accounting maps economic processes so it is a sort of empirical knowledge. Financial accounting is discerned as a formal language and a method of disclosure of a financial position of an economic unit. Moreover the cost accounting is the best example of the theory and the system that arises in a cycle "observations - theory" during an inductive cognition process. Costing systems are designed, tested and implemented. Activity based costing system is an example of a hypothesis that originated from observations of the former systems' matters. Recently that system has been improved into a time-driven activity costing system.

The above speculations are not new. Nor they discover the kernel of accounting. Accounting as a theory and as well as a system is an intellectual activity and - as shown above - fulfills requirements of different classes of sciences. Nevertheless to find the gist of accounting and to prove that our discipline belongs to a narrow class of sciences, that are responsible for the development of civilizations, we have to point at some exclusive traits that are absent in many other disciplines, but are present in accounting. These factors differentiate accounting form other disciplines, such as history or sociology. This special qualities are:

- examination and measurement of abstract core notion,

- deep relation with fundamental laws of Nature,

- mysterious numbers called constants.

All of them are described thoroughly in subsequent sections. 


\section{On the abstract notion and the measurement in accounting}

Pertaining to the measurement feature, the paper by D. W. Vickrey [45] should be recalled, as this author clearly proves that accounting is indeed a measurement discipline, i.e. a discipline, which makes an extensive use of measurement scales (ordinal, interval and ratio scale). Similarly R. Mattessich [36, pp. 63 \& 71] proved that all scales (nominal, ordinal, interval and ratio scale) are broadly used in accounting. Nominal scale is used to differentiate between accounts that are used for journal entries. Ordinal scale is used when an accountant is creating a ranking of investment opportunities. Interval scale is useful in standard costing system and variance analysis. Ratio scale is used when accountants are valuing e.g. capital ${ }^{1}$.

Additionally we have to note that in a narrative language the measure can be described as follows: Measure is a mapping $(m)$ which assigns positive real number $m(A)$ to an asset $A$ and it fulfills three axioms:

1. If asset $A$ does not exist, so $m(A)=0$ (measure is equal to zero).

2. If two assets $A$ and $B$ are separable, then $m(A$ and $B)=m(A)+m(B)$ (measure is additive).

3. If $A$ is included in $B$, then $m(A) \leq m(B)$ (measure is monotonic).

Value determined by a free market exchange or value computed by cost accounting fulfills the above axioms, so they both can be discerned as a measure. Both mentioned measures have their significant role in economy and are known as an exchange value and a cost value.

There are three notions that can be described as the prime set: resources, assets, and capital. These were already thoroughly described by M. Dobija and B. Kurek [19]. However, a short summary of these concepts is required to proceed further, since a number of fundamental differences exists between them. For example capital is measurable, assets are measurable only because of capital that is embodied in them, and resources are only countable.

Recognition of the true character of capital lasted for decades, since its abstract nature and measurability, instead a simple countability, encountered many obstacles. The nature of capital has been examined by many authors, such as J. Ch. Bliss [5] or B. Kurek [34, pp. 11-37]. Current state of knowledge enables us to claim that capital is an ability of doing work. Capital is therefore an abstract, homogeneous category ${ }^{2}$. Capital is embodied in assets. Further understanding of capital stems from the fundamental principles that are recalled in subsequent section. Especially it important to note that capital does not arise from nothing, which is the conservation principle. The second principle the dispersion principle - reveals that capital spontaneously diffuses, if not prevented from doing so.

The first printed book that partly explains the relation between capital and assets, as well as describes a system of a periodical measurement of capital invested in a business, was written by L. Pacioli [40] and was published in Venice in the year 1494. That book covered five topics and accounting was one of them. The accounting part was entitled "Particularis de Computis et Scripturis" ("About Accounts and Other Writings"). We can guess that at least from that time the measurement of the capital growth in business activities became a "common" skill, although L. Pacioli did not invent the system, but just described it. This knowledge is presently known as the two-dimensional double-entry accounting system. The essence of the double-entry recording is still a subject under examination by authors, such as Y. Ijiri [28] and M. Dobija [15], among others.

In order to show the relation between capital and assets, let us consider a very simple statement of financial position of a business. Assets of this firm include only a truck (value of 60000 USD) and a cash on hand (20 000 USD). The appropriate balance sheet of that company is presented in Table 1.

\begin{tabular}{|c|c|c|}
\hline \multicolumn{2}{|c|}{ Assets } & Capital \\
\hline Cash & $\$ 20000$ & Owner's capital $\quad \$ 80000$ \\
\hline Truck & $\$ 60000$ & \\
\hline Total & $\$ 80000$ & $\$ 80000$ \\
\hline
\end{tabular}

Both assets, i.e. a truck and cash, first of all have their specific ability for performing work and second of all - by definition - assets have to assure a stream of inflows to the company, so after a particular period one can expect that the total value of a business will be greater, despite the fact that the value of a truck diminishes. It is the essence of assets. The aim of a firm is to increase the value of capital and this is an indispensable (sine qua non) condition of endurance. The main task of an accounting system is to measure periodical changes of capital - an income when capital increases, and a loss when capital decreases. However, the unit of measure in that system has not yet been clearly understood. It is after all the unit of capital and the notion capital was vague for centuries. Summing up - the value of assets is equal to the value of capital which is embodied in them.

\footnotetext{
${ }^{1}$ On the usage of scales in accounting compare also: [33].

${ }^{2}$ Abstract nature of capital was originally stressed out by Y. Ijiri. Compare: [29].
} 
In order to grasp the idea behind the unit of capital, which is nota bene expressed in a ratio scale, we have to notice the tandem of capital and labor. That tandem is a direct implication from the definition of capital. Capital is the ability of doing work. It is therefore the potential for doing work (e.g. the truck in a garage). Labour process on the other hand is a transfer of this potential of accumulated capital to objects of work. Thus labor (which is in fact a transfer) is a dynamic site of a potential capital. One cannot perform any labor without having capital that was collected earlier. Therefore labor endows unit of measure to capital, so that capital is measured in units of labor.

Summing up, assets are measurable only because capital is embodied in them. In line with the definition of a measure, a measure is always a positive number. The size of this number (value) depends on the concentration of capital in an asset.

The notion of resources is the most uncertain concept. The concept of resources can be briefly explained by clarifying why resources are not assets. Simply because resources are vague and not measurable by labor, and that was the essential feature of assets. Resources may be desirable, but it is not clear if they produce income in future. Resources are counted in natural units, such as tons or cubic meters. If a company procures a land, which covers layers of copper, this land - together with the ore - becomes an asset, since the exchange value is assigned to it.

\section{Fundamental laws and the constant that shape accounting and economic environment}

The application of fundamental principles and constants in physics or chemistry makes these disciplines so different from history or sociology, etc. Such disciplines as history, sociology, and other humanities are in fact parallel narrations of different authors rather than elaborated theories. Instead, sciences have the hard constant dominant core fundamental principles and constants. The fundamental laws and principles are anchors that make sciences stable and real. And that is also the case of the accounting theory. Concluding we may claim that sciences, including accounting, require a different way of thinking than humanities.

A leading scientist M. Gleiser [23, p. 124] pointed out that science is a narrative, where the constants of nature are the letters of alphabet and the laws are the grammar rules. That author stressed that in various sciences a researcher has to be aware of the fundamental laws of Nature and constants that accompany them. The significance of constants was also explained by J. Barrow [3, p. 291], who noticed that constants define the fabric of the Universe. The values of identified constants are manifestations of reality. For example the gravitational constant enables to compute the acceleration of the Earth. After having computed the acceleration, engineers can calculate gravitational forces and are able to plan a structure of contemporary buildings.

The kernel of science is therefore a scientific method, which recognizes the fundamental principles and constants. We aim to prove the scientific provenance of accounting, therefore the question is about the consistency of our discipline with fundamental laws and accompanying constants. Clearly we will not describe strictly chemical or physical laws, but a set of principles that shape our economic environment. Some of these principles have corresponding patterns in physics and cybernetics (Table 2).

The set of principles that shape accounting and economic environment contains six laws:

- the conservation principle accompanied by the classification duality principle,

- the dispersion principle,

- the principle of exponential growth,

- the least action principle ,

- the law of demand,

- the principle of maintaining the existence of autonomous systems.

The first and the second principle have their direct analogies in physics, as presented in Table 2. The laws of thermodynamics are fundamental. Nothing can be correctly explained without them. They are very simple, but at the same time very deep. Fundamental laws are discovered and formulated but not necessarily proved.

P. Atkins [2, p. v] wrote in the preface to his book: "Among the hundreds of laws that describe the universe, there lurks a mighty handful. These are the laws of thermodynamics, which summarize the properties of energy and its transformation from one form to another". The mentioned author reminds the readers that thermodynamics is not only about steam engines, but it is almost about everything, including processes of life.

The first and the second principle significantly shape economic environment. Without them we could not measure periodic income and understand the nature of profit. The two dimensional double-entry bookkeeping directly stems from the first law, particularly its part, which informs that ability for doing work (i.e. capital) does not arise from nothing. Therefore accounting system uses the double-entry recording as the core rule.

The second law describes the spontaneous diffusion of capital. That principle can be mathematically described in the form of equation number (1):

$\mathrm{C}_{\mathrm{t} 1, \mathrm{~s}}=\mathrm{C}_{\mathrm{t} 0} \times \mathrm{e}^{\mathrm{s} \times \Delta \mathrm{t}}$

where: 
$\mathrm{C}_{\mathrm{t} 0}$ - the beginning concentration of capital [expressed in monetary terms] in the time moment $\mathrm{t} 0$,

$\mathrm{C}_{\mathrm{t} 1, \mathrm{~s}}$ - the ending concentration of capital [expressed in monetary terms] in the time moment $\mathrm{t} 1$, which has been subdued to natural dispersion "s" (risk) through the time period $\Delta \mathrm{t}$,

$\mathrm{s}$ - dispersion variable (risk) [expressed as $1 /$ year],

$\Delta \mathrm{t}$ - time period between time moments: $\mathrm{t} 0$ and $\mathrm{t} 1$ [expressed in years].

The second law additionally explains a concept of the fair pay. The fair pay is an amount that covers the spontaneous and random diffusion of employee's human capital.

F. Knight [31] tried to explain a difference between uncertainty and risk. He pointed out that there was a relation between an income and uncertainty. The later one is undeniably a consequence of the second law. However, neither risk nor uncertainty are sources of profit. Profit is strictly connected to the third principle.

Table 2: List of fundamental principles shaping accounting and economic environment

\begin{tabular}{|c|c|c|}
\hline & $\begin{array}{c}\text { The fundamental } \\
\text { economic principles }\end{array}$ & $\begin{array}{l}\text { Patterns in physics and } \\
\text { cybernetics }\end{array}$ \\
\hline 1 & $\begin{array}{l}\text { The conservation principle of capital states that capital does not arise from } \\
\text { nothing nor disappears in internal operations of a company. In another words it } \\
\text { is impossible to create or destroy capital by journal entries that are internal to } \\
\text { the company. Capital flows through a labor process, which is a way of injecting } \\
\text { capital into a company. } \\
\text { The classification duality principle describes the essence of the double } \\
\text { classification in accounting and coexistence of assets and capital. According to } \\
\text { that duality, a concentration of capital is embodied in assets, hence the equality } \\
\text { of assets and capital in currency terms. }\end{array}$ & $\begin{array}{l}\text { The first law of } \\
\text { thermodynamics, i.e. energy } \\
\text { conservation principle. }\end{array}$ \\
\hline 2 & $\begin{array}{l}\text { The dispersion principle states that every concentration of capital is subdued to } \\
\text { a random and spontaneous diffusion. That principle is not contrary to the } \\
\text { conservation principle as the dispersion principle refers to a company and its } \\
\text { environment. }\end{array}$ & $\begin{array}{l}\text { The second law of } \\
\text { thermodynamics. }\end{array}$ \\
\hline 3 & $\begin{array}{l}\text { The principle of exponential growth of capital invested in business activities } \\
\text { results from an economic constant of potential growth. The average growth rate } \\
\text { is close to } 8 \% \text { per year. }\end{array}$ & Lack of a relevant principle. \\
\hline 4 & $\begin{array}{l}\text { The least action principle determines the way successful economic actions are } \\
\text { executed. A cost is an economic category and determines outlays, which are } \\
\text { indispensable for the planned aim. }\end{array}$ & The least action principle. \\
\hline 5 & $\begin{array}{l}\text { According to the law of demand it is highly probable that a quantity of a } \\
\text { commodity demanded is in a reversal proportion to a price of that commodity. } \\
\text { Supply and demand establish an exchange value. }\end{array}$ & Lack of a relevant principle. \\
\hline 6 & $\begin{array}{l}\text { The principle of maintaining the existence of autonomous systems. According } \\
\text { to this principle such systems act in their own business aiming at the } \\
\text { maintenance of their existence. This principle determines perception and } \\
\text { understanding of organizations, states, businesses and individuals in the } \\
\text { economic considerations. }\end{array}$ & $\begin{array}{l}\text { Cybernetics. Theory } \\
\text { autonomous systems. }\end{array}$ \\
\hline
\end{tabular}

Source: updated version of [19].

The principle of exponential growth of capital invested in business activities is a result of an economic constant. If the market did not reward economic agents, nobody would undertake economic activities, as their concentration of capital would deteriorate according to the second principle. The manifestation of the constant can be mathematically described in the form of equation number (2):

$\mathrm{C}_{\mathrm{t} 1, \mathrm{p}}=\mathrm{C}_{\mathrm{t} 0} \times \mathrm{e}^{\mathrm{p} \times \Delta \mathrm{t}}$

where:

$\mathrm{C}_{\mathrm{t} 0}$ - the beginning concentration of capital [expressed in monetary terms] in the time moment $\mathrm{t} 0$,

$\mathrm{p}$ - economic constant of potential growth, $\mathrm{p}=\mathrm{E}(\mathrm{s})$ [expressed as $1 /$ year],

$\mathrm{C}_{\mathrm{t} 1, \mathrm{p}}$ - the ending concentration of capital [expressed in monetary terms] in the time moment $\mathrm{t}$, which has been subdued to economic constant of potential growth " $p$ " through the time period $\Delta t$,

$\Delta \mathrm{t}$ - time period between time moments: $\mathrm{t} 0$ and $\mathrm{t} 1$ [expressed in years].

Additionally managers of companies through labor and good management $\mathrm{M}$ may try to limit natural dispersion. That is the third variable that influences the concentration of capital invested in business activities. All these variables taken together describe the ending concentration of capital, which can be mathematically described in the form of equation number (3):

$\mathrm{C}_{\mathrm{t} 1, \mathrm{~s}, \mathrm{p}, \mathrm{M}}=\mathrm{C}_{\mathrm{t} 0} \times \mathrm{e}^{(\mathrm{p}-\mathrm{s}+\mathrm{M}) \times \Delta \mathrm{t}}$ 
where:

$\mathrm{C}_{\mathrm{t} 0}$ - the beginning concentration of capital [expressed in monetary terms] in the time moment $\mathrm{t} 0$,

$\mathrm{C}_{\mathrm{t} 1, \mathrm{~s}, \mathrm{p}, \mathrm{M}}$ - the ending concentration of capital [expressed in monetary terms] in the time moment $\mathrm{t} 1$, which has been subdued to natural dispersion "s" (risk), economic constant of potential growth "p" and a management variable "M" through the time period $\Delta \mathrm{t}$,

$\mathrm{s}$ - dispersion variable (risk) [expressed as 1/year],

$\mathrm{p}-$ economic constant of potential growth, $\mathrm{p}=\mathrm{E}(\mathrm{s})$ [expressed as 1/year],

$\mathrm{M}$ - management variable [expressed as $1 /$ year],

$\Delta \mathrm{t}$ - time period between time moments: $\mathrm{t} 0$ and $\mathrm{t} 1$ [expressed in years].

Summing up, the economic constant of potential growth as well as activities of managers (and all labor force) are sources of profit, as these two variables influence positively the beginning concentration of capital invested in business activities. Uncertainty and risk act in the opposite way. The result of these three variables in the change in the beginning concentration of capital invested in business activities.

Accounting as a measurement discipline measures periodical changes in capital invested in business activities. That change is hopefully a profit. It can be proved that on average managers succeed in achieving profits. These profits correspond to the level of an economic constant of potential growth and to the level of capital involved in business activities, as well as to the skills of managers and risk. The research conducted by B. Kurek [34], who used large sets of data leads to the conclusion that the yearly average value of a ratio of profit to total capital (ROA) is pretty stable and close to eight percent. Therefore we claim that the invested capital grows according to the compound interest formula, which is the essence of the principle of exponential growth. Applying a wider interpretation we may conclude that the game with Nature is the positive non-zero sum game. The Nature enables growth on the level close to eight percent per year. Significant number of research papers also suggests that the average return on human capital (fair minimum salaries and wages) is close to eight percent per year.

The least action principle in the fourth law. That law is of the greatest significance for both physics and economics. A researcher of MIT, D. Dalrymple [8] claims: "At least for me, the least action perspective explains all known physics as well as the origin of our universe". This author explains further that: "A principle of least action does not explicitly specify what will happen, like an equation of motion does, but simply asserts that the action will be the least of any conceivable actions. In some sense, the universe is maximally efficient. To be precise, the action integrated over any interval of time is always minimal". Such economic categories as the concept of cost and the concept of optimization are deeply related to the least action principle. A cost as defined by E. Burzym [6, pp. 107-109] is the least outlays necessary for accomplishing a given task. What is over is a loss. Cost control tends to keep costs on the right level not allowing for losses. We humans choose ways, which lead directly to our aim saving energy and time (in physics: action $=$ energy $\times$ time). Optimization should assure that some planned aim will be achieved at the least costs and time (in economics: action $=$ capital $\times$ time ) . Moreover, when conducting economic activities people strive for saving actions in order to gain expected profits. The gain of a value added is an engine of economic activities.

Law of demand is the fifth principle. Undeniably supply and demand are important economic categories. After having examined with scrutiny behaviors of prices and quantities demanded (offered) at these prices economists concluded that with a high degree of probability we can claim that the quantity of goods, commodities and services demanded is in a reversal proportion to their prices. Some paradoxes, such as the Veblen one and the Giffen one are also known and described thoroughly in the economic literature. Individuals conducting their businesses on the market have to respect this law, treating it as a feature and a constraint of reality.

The principle of maintaining the existence of autonomous systems is the sixth principle shaping accounting and economic environment. M. Mazur [38], who is the originator of the autonomous system theory, points out that an autonomous system is a system that is able to control itself, and is able to preserve its ability to control itself. The last condition requires the existence of an organ that maintains functional equilibrium of energetic and information processes, i.e. homeostasis. In order to control itself the autonomous system requires organs for reception and accumulation, both: energy and information. M. Mazur's research (conducted purely from the point of view of physics) shed some light on perception of all autonomous systems, which tend to maintain their existence. States, companies, humans, animals belong to the class of autonomous systems. In these cases the own business of every being is the dominating, overwhelming motivation of life and actions. Additionally the equilibrium is a feature of an existing autonomous system. The state of equilibrium is clearly definable as the continuous maintenance of feedbacks among subsystems forming the entire system. Further issues concerning homeostasis are presented in section 4.

\section{Homeostasis and prospective accounting information}

M. Mazur [38, pp. 99-111] correctly noticed that decision problems need adequate scientific approaches. A system method of analysis leads to the conclusion that all possible problems can be divided into six groups. The first three are cognitive, and they relate to the cognition of: facts, properties, and relations. The last three are decision problems and 
they relate to decision-making on: purposes, methods, and means. Decision problems include: postulation, optimization, and realization. Sciences examine both cognitive and decision problems.

M. Mazur also developed the theory of control and maintenance of homeostasis by autonomous systems. This author defines control as such a behavior of one system, that provokes the predetermined behavior of another system [38, 438]. In each control process there must be a mutual dependence of purposes on methods and means.

The general scheme of control process described by R. Bellman [4, p. 39] uses the general idea of a variance between an existing state and an expected state of a subsystem. This idea was adjusted by M. Dobija [11, p. 49] and may be applied to control of economic processes, as depicted in Fig. 1.

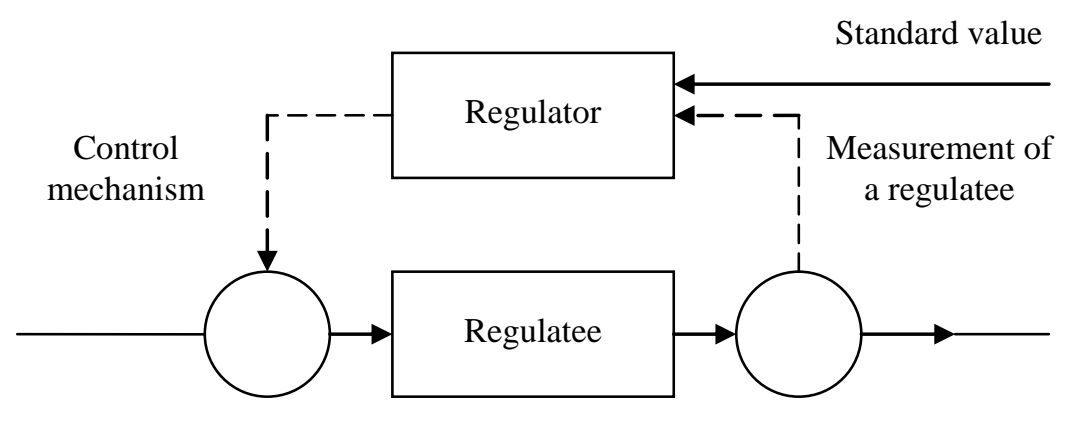

Fig. 1: The structure of a regulation circuit Source: [11, p. 49].

The theory of control explains that future values of variables involved in the controlled system are the indispensable parts of a controlling process. It is true both in automatic control of chemical processes, and in managerial control of business activities. Budgets, which are products of managerial accounting system, are good examples of the managerial control system. Budgeting process fulfills many tasks in a company, since a budget is a consistent quantitative description of planned business activities in a budgeted period. The budget, from the steering point of view, includes the set of standard and expected values of economic variables. Thus budgeting process updates the standard values apparent on figure 1. Successful budgetary control is the important factor essential for the maintenance of a company in a state of internal equilibrium, i.e. in homeostasis.

Accounting, through its control function, enables the appearance of the two aspects of an object together: the embodied capital and the equilibrium. The best well known example is a company, which survival is linked to the growth of equity capital. The other important example is an employee, who strives for sustaining his/her human capital. Human capital should not decrease, as the success or failure is equaled with the famous statement to be or not to be. The role of an accounting system in sustaining the company's equilibrium is well recognized in literature. Instead the role of our discipline in serving employees is still in its beginning phase, although studies in this matter have already been conducted, including the accounting for intellectual capital of a company [10], the human capital model [7], the derived model of the fair compensation [32], and the human capital theory accompanied with the theory of fair salaries [14]. Research made and described in these publications provides fundamentals for human capital accounting and reporting. From time to time members of our society are concerned about accounting, accountants and they services. These opinions result from dissemination of bad news that relate to our profession, including, but not limited to, financial scandals. One of the common methods used by media is to assign a depreciatory semantic meaning to virtually positive phrases, such as: "creative accountant" or "creative accounting". That procedure is mainly used when new financial scandal or a spectacular failure of a large company hits the market. It is a manifestation of a poor understanding of an accounting role and its possibilities.

Accounting has numerous tasks. One of the major ones is the determination of a financial position of a company. To complete this task, the process of valuation has to be completed. Valuation requires an assignment of a measure of an abstract capital embodied in different assets in a particular time moment. That explains the difficulties associated with this process and thus with this major task. Moreover, accountants are not alone in this process. Inflation or deflation pressure, expectations of investors generate a turbulent environment for the valuation process.

Accounting theory is equipped with some fundamental rules concerning valuation. These are: historical cost principle and LCMP (lower historical cost or market price). The application of this rule provides a safe and conservative valuation when applied to most of assets, excluding land. The need for the valuation of land as well as financial assets (e.g. options, forward contracts) made the standard setting committees propose hardly determined "fair value" as a major valuation concept. The former conservative feature of valuation was loosened. From the other side a determination of an exact value of capital in various sorts of financial assets is a task that cannot be performed. Valuation is after all an estimation process. 
Accounting theory and practice have to be updated to the current world situation. Therefore standard setters establish numerous standards that determine principles of valuation for the different classes assets. This is the reason why accounting theory and practice become more and more complicated, demanding and challenging. Accountants are aware of their responsibilities in this matter. Auditing firms are leaders in creating the restructured future accounting systems.

The outer environment of accounting is strongly affected by major economic factors, in particular the monetary activities of the Central Banks and Governments. Inflation is one of the examples of factors, which disturb capital measurement in economic processes. By the same token deflation disturbs the measurement of capital. In general, stability of a money unit is not an agenda for accounting theory and practice. Regrettably, theory of money and practices of institution responsible for money are not perfect. That is a common knowledge. Therefore in these circumstances the measurement offered by accounting theory and its systems cannot be perfect neither. This situation indicates that the science of accounting is still full of challenges. Accounting develops constantly and a range of papers explore new paths and show new directions for studies. Some satisfactory examples include accounting for labor, which was described by M. Dobija and M. Jędrzejczyk [16] or by M. Dobija and B. Kurek [17], [18]. Other examples include human capital costing and accounting. These considerations are strongly correlated with the correct theory of money, according to which money arises as a result of work, and not as a result of banknotes emitted by a central bank.

\section{Conclusion}

The presented considerations aimed at pointing out that accounting and its theory, although included in the set of disciplines called "economics", belong to the family of disciplines denoted as "science" as well. Therefore in section 1 the kernel of science and accounting was searched for. In section 2, the concept of measure was enlightened, and the unit of measure was determined. A category of capital was shown as the only abstract notion hidden in assets, which is measured in accounting systems according to the theoretical guidelines of double-entry accounting. Moreover, it appeared that sciences, including accounting and its theory, obey the fundamental laws and are subdued to the numbers called constants. The laws that play a significant role in accounting and its theory were described in section 3 .

Three laws can be described as the most general ones, as they originate from physics: the conservation principle (in physics known as the first law of thermodynamics), the dispersion principle (in physics known as the second law of thermodynamics) and the least action principle (in physics under the same name). The conservation principle explains why capital cannot arise from nothing. The dispersion principle explains that capital embodied in assets diffuses spontaneously and unavoidably. The least action principle denotes the efficiency of systems.

The subsequent two laws belong strictly to economics. These are: the principle of exponential growth of capital involved in economic activities and the law of demand. The former one is closely related to accounting theory. The latter one has cybernetics provenance. It helps to understand that economic agents strive for the maintenance of equilibrium. This law shows the nature and tasks of the management accounting. Section 4 deliberates on accounting control and management agendas.

Concluding we should say that accounting is the theory and the practice of measurement of capital. As such accounting assesses capital embodied in assets of economic units in a particular point of time. That is a fundamental feature of accounting necessary for financial reporting. Accounting therefore enables its users to gain a retrospective picture. Additionally accounting provides its users with a prospective picture, by facilitating managerial control through organization of budgets and budgetary controls. Accounting practice is the intellectual activity, which is strongly controlled by accounting theory. Both sides of accounting, the theoretical and practical, serve civilization as indispensable knowledge. Accounting is a part of economics, however it is also a part of science, too, as its theory is internally consistent, obeys the fundamental laws, and is subdued to the numbers called constants.

\section{Acknowledgements}

We would like to thank the participants of the $5^{\text {th }}$ International Scientific Conference: Knowledge-Economy-Society organized in Krakow (Poland) by Faculty of Management at Cracow University of Economics on $5^{\text {th }}-7^{\text {th }}$ June 2013 for their precious comments.

\section{References}

[1] Apanowicz J., Metodologiczne elementy procesu poznania naukowego w teorii organizacji i zarządzania, Gdynia: WSAiB, (2000).

[2] Atkins P., Four Laws that Drive the Universe, New York: Oxford University Press, (2007). 
[3] Barrow J. D., The Constant of Nature: From Alpha to Omega, London: Jonathan Cape, (2002).

[4] Bellman R., Adaptacyjne procesy sterowania, Warszawa: Polskie Wydawnictwo Naukowe, (1965).

[5] Bliss Ch., Capital Theory and the Distribution of Income, Oxford: North-Holland Publishing, (1975).

[6] Burzym E., Pomiar i ocena rentowności przedsiębiorstw przemysłowych, Warszawa: Państwowe Wydawnictwo Ekonomiczne, (1971).

[7] Cieślak I., Dobija M., "Teoretyczne podstawy rachunkowości kapitału ludzkiego", Zeszyty Naukowe Uniwersytetu Ekonomicznego w Krakowie, Nr 735, (2007), pp. 5-24.

[8] Dalrymple D., The Principle of Least Action, available online: http://edge.org/response-detail/11722.

[9] Demski J. S., "Is Accounting an Academic Discipline?", Accounting Horizons, Vol. 21, No. 2, (2007), pp. $153-157$.

[10] Dobija D., Pomiar i sprawozdawczość kapitału intelektualnego przedsiębiorstwa, Warszawa: Wydawnictwo Wyższej Szkoły Przedsiębiorczości i Zarządzania im. Leona Koźmińskiego, (2003).

[11] Dobija M., Rachunkowość zarządcza i controlling, Warszawa: Wydawnictwo Naukowe PWN, (2002).

[12] Dobija M., "Rachunkowość jako dyscyplina naukowa“, Zeszyty Teoretyczne Rachunkowości, Vol. 59 (115), (2010), pp. 25-39

[13] Dobija M., "Abstract Nature of Money and the Modern Equation of Exchange", Modern Economy, Vol. 2, No. 2, (2011), pp. 142-152.

[14] Dobija M. (ed.), Kapitał ludzki w perspektywie ekonomicznej, Kraków: Wydawnictwo Uniwersytetu Ekonomicznego w Krakowie, (2011).

[15] Dobija M., "Ponadczasowe i cywilizacyjne znaczenie zapisu podwójnego", Management and Business Administration. Central Europe, No. 4 (117), (2012), pp. 3-22.

[16] Dobija M., Jędrzejczyk M., Szkice z historii rachunkowości, Kraków: Polskie Towarzystwo Ekonomiczne, (2011).

[17] Dobija M., Kurek B., Concepts of Physics in Accounting and the Money-Goods Economy; Capital and Labour Issues [in:] Dobija M., Martin S. (eds.), General Accounting Theory. Towards Balanced Development, Kraków: Akademia Ekonomiczna w Krakowie, (2005), pp. 51-86.

[18] Dobija M., Kurek B., "Istota pracy w fizyce i rachunkowości”, Zeszyty Naukowe Uniwersytetu Ekonomicznego w Krakowie, Nr 796, (2009), pp. 33-45.

[19] Dobija M., Kurek B., “Towards Scientific Economics”, Modern Economy, Vol. 4, No. 4, (2013), pp. 293 -304.

[20] Ellerman D., "The Mathematics of Double Entry Bookkeeping", Mathematics Magazine, Vol. 58, No. 4, (1985), pp. $226-233$.

[21] Ellerman D., "Double Entry Multidimensional Accounting", International Journal of Management Science, Vol. 14, Issue 1, (1986), pp. 13-22.

[22] Fellingham J. C., "Is Accounting an Academic Discipline?", Accounting Horizons, Vol. 21, No. 2, (2007), pp. 159-163.

[23] Gleiser M., Nie ma nic złego w tym, że nie wiemy wszystkiego [in:] Brockman J. (ed.), Niebezpieczne idee we współczesnej nauce, Sopot: Wydawnictwo Smak Słowa i Wydawnictwo Academica, (2008).

[24] Gove P. B. and the Merriam-Webster Editorial Staff (eds.), Webster's Third New International Dictionary of the English Language. Unabridged, Cologne: Könemann, (1993).

[25] Hatfield H. R., “An Historical Defense of Bookkeeping”, Journal of Accountancy, Vol.37, No.4, (1924), pp. $241-253$.

[26] Ijiri Y., "Theory of Accounting Measurement", Studies in Accounting Research, No. 10, Sarasota, Florida: American Accounting Association, (1975).

[27] Ijiri Y., The Foundations of Accounting Measurement, Houston, Texas: Scholars Book Co., (1978), (1 ${ }^{\text {st }}$ ed. 1967).

[28] Ijiri Y., "The Beauty of Double-Entry Bookkeeping and Its Impact on the Nature of Accounting Information", Economic Notes, Vol. 22, No. 2, (1993), pp. 265-285.

[29] Ijiri Y., "Segment Statements and Informativeness Measures: Managing Capital vs. Managing Resources”, Accounting Horizons, Vol. 9, No. 3, (1995), pp. 55-67.

[30] Jaruga A. A., Systemy regulacji rachunkowości a międzynarodowa harmonizacja i standaryzacja [in:] Jaruga A. A. (ed.), Międzynarodowe regulacje rachunkowości. Wpływ na rozwiązania krajowe, Warszawa: Wydawnictwo C. H. Beck, (2002), pp. 1-21.

[31] Knight F., Risk, Uncertainty, and Profit, Boston, MA: Hart, Schaffner \& Marx; Houghton Mifflin Company, (1921), available online: http://www.econlib.org/library/Knight/knRUP7.html.

[32] Kozioł W., Kształtowanie płac stałych na podstawie rachunku kapitału ludzkiego, [in:] Dobija M. (ed.), Teoria pomiaru kapitału i zysku, Kraków: Wydawnictwo Uniwersytetu Ekonomicznego w Krakowie, (2010), pp. 73-100.

[33] Kurek B., ’Jednostka skali ilorazowej w rachunkowości kosztów pracy”, Zeszyty Naukowe Akademii Ekonomicznej w Krakowie, Nr 735, (2007), pp. 69-82.

[34] Kurek B., Hipoteza deterministycznej premii za ryzyko, Kraków: Uniwersytet Ekonomiczny w Krakowie, (2011).

[35] Kwiecień M., Rozwój rachunkowości a konwergencja jej koncepcji - praktyka na świecie [in:] Nowak E. (ed.) Paradygmaty rachunkowości, Wrocław: Wydawnictwo Akademii Ekonomicznej we Wrocławiu, (2007).

[36] Mattessich R., Accounting and Analytical Methods, Homewood, Illinois: Richard D. Irwin, Inc., (1964).

[37] Mattessich, R., Critique of Accounting. Examinations and the Foundations and Normative Structure of an Applied Discipline, London: Quorum Books, Westport, (1995).

[38] Mazur M., Cybernetyka i charakter, Warszawa: PIW, (1976).

[39] Micherda B., "Analityczna funkcja rachunkowości w okresie przejściowym do gospodarki rynkowej", Zeszyty Naukowe Akademii Ekonomicznej w Krakowie, Seria specjalna: Monografie, Nr 129, Kraków: Akademia Ekonomiczna w Krakowie, (1997).

[40] Pacioli L., Summa de Arithmetica, Geometria, Proportioni et Proportionalita, Venice, (1494).

[41] Peche T., Wiadomości wstępne [in:] Peche T. (ed.), Teoretyczne podstawy rachunkowości, Warszawa: Państwowe Wydawnictwo Ekonomiczne, (1988), pp. 13-64.

[42] Rozporządzenie Ministra Nauki i Szkolnictwa Wyższego z dnia 8 sierpnia 2011 r. w sprawie obszarów wiedzy, dziedzin nauki i sztuki oraz dyscyplin naukowych i artystycznych, Dz. U. z 2011 r. Nr 179, poz. 1065.

[43] Surdykowska S. T., Rachunkowość międzynarodowa, Zakamycze: Kantor Wydawniczy Zakamycze, (1999).

[44] Szychta A., "Współczesne kierunki zainteresowania teorii rachunkowości finansowej w świetle zarysu jej rozwoju", Zeszyty Teoretyczne Rachunkowości, No. 56 (112), (2010), pp. 245-265.

[45] Vickrey D. W., "Is Accounting a Measurement Discipline?", The Accounting Review, Vol. 45, No. 4, (1970), pp. 731-742. 